\title{
On the Scientific Status of Literary Physiognomics in Victorian Realism: The Novels of Charlotte Brontë
}

In late June 1851, Charlotte Brontë and her publisher, George Smith, visited a certain Dr J.P. Browne, of 367 Strand, London. Browne was a well-known phrenologist, and for the purpose of getting their heads anonymously measured and readk, Brontë and Smith assumed the pseudonyms of $\mathrm{Mr}$ and Miss Fraser. The result of this assessment was sent to Smith, who did not immediately forward it to Charlotte Brontë, about which she complained after her return to Haworth on 1 July 1851: "Do not keep it back on account of any faults. ${ }^{1}$ In the same letter, she urged him to send it to her regardless of its content: »[R]emember Thackeray seems to think our faults the best part of us. I will tell you faithfully whether it seems to me true or not. « $^{2}$ A few days later, Smith finally sent Browne's estimate to Brontë. Her reply praises above all Smith's character assessment, which she thought to be "like - like - like as the very life itself. $\ll^{3}$ Her opinion on the phrenological results of her own head and skull, however, were more restrained. Here is a longer excerpt from Dr Browne's »Phrenological Estimate of the Talents and Dispositions of a Lady«:

Her sense of truth and justice would be offended by any dereliction of duty, and she would in such cases express her disapprobation with warmth and energy [...]. She is sensitive and is very anxious to succeed in her undertakings, but is not so sanguine as to the probability of success. She is occasionally inclined to take a gloomier view of things than perhaps the facts of the case justify [...]. Her imitative powers are good, and the faculty which gives manual dexterity is well developed. These powers might have been cultivated with advantage [...]. She is endowed with an exalted sense of the beautiful and ideal, and longs for perfection. If not a poet her sentiments are poetical or are at least imbued with that enthusiastic glow which is characteristic of poetical feeling. She is fond of dramatic literature and drama, especially if it be combined with music. In its intellectual

1 Charlotte Brontë: The Letters of Charlotte Brontë, 3 vols., ed. by Margaret Smith, Oxford 1995-2007, vol. 2, p. 655.

2 Ibid.

3 Ibid., p. 657. 
development this head is very remarkable. The forehead is at once very large and well formed. It bears the stamp of deep thoughtfulness and comprehensive understanding. It is highly philosophical. It exhibits the presence of an intellect at once perspicacious and perspicuous. There is much critical sagacity and fertility in devising resources in situations of difficulty, much originality, with a tendency to speculate and generalize. [...] This lady possesses a fine organ of language, and can, if she has done her talents justice by exercise, express her sentiments with clearness, precision, and force - sufficiently eloquent but not verbose [...]. In analyzing the motives of human conduct, this lady would display originality and power, but in her mode of investigating mental science she would naturally be imbued with a metaphysical bias - She would perhaps be skeptical as to the truth of Gall's doctrine - But the study of this doctrine, this new system of Mental Philosophy, would give additional strength to her excellent understanding by rendering it more practical, more attentive to particulars, and contribute to her happiness by imparting to her more correct notions of the dispositions of those whose acquaintance she may wish to cultivate - J.P. Browne M D. ${ }^{4}$

The accuracy of Dr Browne's estimate has been noted by many Brontë scholars. ${ }^{5}$ Yet twenty-first century readers will hardly believe that Browne's detailed assessment is the result of his phrenological skills and craniometrical measurements alone. Many of his correct judgments must certainly have derived from his observation of Brontë and Smith's behavior. His estimate of her linguistic skills (»a fine organ of language«), for instance, was likely influenced by the conversation that must have taken place during the elaborate measuring of her skull. This probably also accounts for his evaluation of Brontë as a philosophical thinker (»the forehead [...] is highly philosophical«). In any case, it is interesting that Browne concludes his analysis with the remark that the analyzed lady "would perhaps be skeptical as to the truth of Gall's doctrine, « referring to Franz Joseph Gall, the founder of phrenology. Many scholars would disagree, and I join them in believing that the visit to Dr Browne reinforced Brontë's strong belief in phrenology and physiognomics, ${ }^{6}$ as is manifest in the three novels that she had already

4 Ibid., pp. 657-659.

5 See for instance Sally Shuttleworth: Charlotte Brontë and Victorian Psychology, Cambridge 1996, p. 57. The episode is also mentioned in Elizabeth Gaskell: The Life of Charlotte Brontë, ed. by Angus Easson, Oxford 2009, pp. 384-385. It has been critically discussed by, among others, Winifred Gérin: Charlotte Brontë: The Evolution of Genius, Oxford 1967, pp. 576-578, and by Wilfred Minnich Senseman: Charlotte Brontë's Use of Physiognomy and Phrenology, in: Papers of the Michigan Academy of Science, Arts, and Letters 38 (1953), pp. 475-486, here pp. 475-476.

6 Throughout this paper I prefer the more precise term sphysiognomics over the more idiomatic sphysiognomy<, a distinction that is well-established in languages other than 
written at that time (The Professor, Fane Eyre, and Shirley). In her next novel, Villette, there is no sign of any growing doubt as to the validity of either phrenology or physiognomics. In fact, Villette is, as Sally Shuttleworth correctly states, "permeated by the language and assumptions of phrenology. " ${ }^{7}$ Graeme Tytler also notes that, when investigating these pseudo-sciences, Villette is the "one work of fiction you know you simply cannot omit from your discussion [...]. Few novels«, he continues, "could match this one for abundance of physical character description; indeed, in some respects it may be said to have gone too far in that direction, embodying as it does many familiar physiognomic ideas, and even a few phrenological ones «. ${ }^{8}$ All of Brontë's fictional texts are to be considered as affirmative of physiognomic discourse, both her early Angrian tales, and her later, mature novels. Of all major canonical Victorian writers, Charlotte Brontë is perhaps the only one whose firm belief in physiognomics (and its consequent application as a literary technique) never wavered. It is therefore not without irony that Dr Browne's astonishingly accurate phrenological interpretation was nevertheless completely mistaken on the subject of Brontë's interest and faith in phrenology.

In this article, I explore how and why Brontë's novels employ physiognomics and phrenology as literary devices to represent the world ras it is $<$ - the standard motto of the realist enterprise. In the texts, both systems are invested with a scientific validity that enables their precision and infallibility in judgment. In Brontë's novels, it appears as if these pseudo-sciences were indeed able to access the invisible inner character by reading the visible outer surface. Interestingly, physiognomists and phrenologists alike use their skills to navigate safely through foreign cultural surroundings: as Anglicans in Catholic Belgium, as women in patriarchal society, or as members of the lower classes in the world of the gentry. Simultaneously, their efforts to prosper in these allegedly hostile surroundings demonstrate their latent racism, sexism, or

English. P Physiognomics` always refers to the science or practice (Greek: téchne) of reading faces, while sphysiognomy is the face or "physical appearance itself $(O E D$, "physiognomy, n."). The OED (Oxford English Dictionary) lists both terms, noting that "physiognomics, n.", meaning "the art or practice of judging character from facial or physical characteristics", is "[n]ow chiefly hist." (OED, "physiognomics, n.«). Quotations from historical, scientific, scholarly, and literary sources rarely follow this distinction, and therefore remain unchanged in this paper; the context should make it sufficiently clear which term is meant.

7 Sally Shuttleworth: Charlotte Brontë and Victorian Psychology, p. 57.

8 Graeme Tytler: Lavater and the Nineteenth-Century English Novel, in: The Faces of Physiognomy: Interdisciplinary Approaches to Johann Caspar Lavater, ed. by Ellis Shookman, Columbia 1993, pp. 161-180, here p. 179. 
classism, as they use their physiognomic and phrenological skills to ostracize others, and to assert their authority as frugal, diligent, and pious British protestants over allegedly lavish, slovenly, and sanctimonious continental Europeans or non-Europeans. Physiognomics' originally philanthropic orientation - notably Lavater's design to "promote the knowledge and the love of mankind « - thus yields to an intersectional discrimination that uses (or misuses) the physiognomic framework in order to put its judgments on seemingly solid scientific ground. I have selected passages from three of Brontë's novels, The Professor, Fane Eyre, and Villette, in order to demonstrate both her belief in, and her exploitation of literary physiognomics. As the prefatory report of her visit to the London phrenologist demonstrates, Charlotte Brontë's personal opinions are often congruent with those of her fictional characters. This is not to say, however, that we should (or even could) deduce the author's convictions from her literary texts, or that we should use extra-textual evidence like the above-mentioned letter to interpret her novels. To avoid confusion, I will attempt to carefully distinguish between physiognomic practice on the one hand, and literary physiognomics on the other. Despite their occasional overlapping, I will maintain that they nevertheless delineate two distinct historical and epistemological spheres. Keeping this in mind will enable us to explain, among other things, why the triumph of literary physiognomics in British literature came at a time when the influence of physiognomic practice was clearly waning in the British Isles.

\section{The Waning Influence of Physiognomic Practice in Victorian England and its Triumph in the Realist Novel}

In his Essays on Physiognomy, Lavater repeatedly asserted the scientific status of physiognomics:

Whoever will take the trouble, which every child has the power of taking, of assuming those principles which all sciences have in common, [...] will no longer during his life, object that physiognomy is not scientific. Either he must allow the appellation scientific to physiognomy, or deny it to whatever is at present denominated science. ${ }^{9}$

9 Unless otherwise noted, all quotations of Lavater's Essays are taken from Thomas Holcroft's early English translation: Johann Caspar Lavater: Essays on Physiognomy, designed to Promote the Knowledge and Love of Mankind, trans. by Thomas Holcroft, $8^{\text {th }}$ ed., London 1853, https://archive.org/stream/04851455.5902.emory.edu/ (last accessed 14 
What is at stake for Lavater's enterprise is the validity of his discipline. Only if physiognomics proves itself able to yield consistent results can it justly be called a science. This explains phrases frequently recurring in all of his volumes, such as »objective physiognomy «, ${ }^{10}$ and the »incontrovertible certainty of the truth «, ${ }^{11}$ as well as his demands for "the most scrupulous attention to their truth «. ${ }^{12}$ His presumption to call physiognomics the "most divine science ${ }^{13}$ hints at the theological dimension that Lavater ascribes to the sciences, and also at the fact that he repeatedly confuses different spheres of knowledge. The central object of this alleged science is, according to Lavater, man himself. The competent physiognomist sees through the visible surface into the inner soul and character of man, and, if he uses the correct "method to be employed in physiognomical observation ",${ }^{14}$ his diagnostic analysis will be unambiguous, immune to fallacies, and, above all, objective.

Despite their great popularity, the Essays on Physiognomy soon came under attack from various sides: from Georg Christoph Lichtenberg and his popular satire on Lavater, Fragment von den Schwänzen (»Essay on Tails«, with a pun in German on both the words tassel and penis), from Johann Wolfgang von Goethe, who had been for some time Lavater's friend and traveling companion, but distanced himself in the early 1780s and eventually broke with

November 2015). Since much of Lavater's enthusiastic diction gets lost in Holcroft's (incomplete) translation, I have translated a few of the passages myself. All references to Lavater henceforth cited as Essays/Fragmente. I first indicate page number and title of the essay in English, for the convenience of readers with different Lavater editions, and then the according essay title and page number in the original German edition: Johann Caspar Lavater: Physiognomische Fragmente, zur Beförderung der Menschenkenntniß und Menschenliebe, 4 vols., Leipzig/Winterthur 1775-1778, in: Deutsches Textarchiv, http:// www.deutschestextarchiv.de/lavater_fragmente01_1775 (last accessed 14 November 2015). Wherever the translation is my own, I reference only the German original. The quoted passage is from the essay »Physiognomy a Science«, p. 37 (German: "Die Physiognomik, eine Wissenschaft«, vol. 1, pp. 52-53).

10 Fragmente: »Von den oft nur scheinbaren Fehlschlüssen des Physiognomisten«, vol. 1, p. 136; translation mine, E.K.

11 Essays: »On Shades«, p. 189 (German: »Ueber Schattenrisse«, vol. 2, p. 91).

12 Essays: "On the Study of Physiognomy Addressed to Count Thun, At Vienna«, p. 137 (German: „Ueber das Studium der Physiognomik, an Herrn Grafen von Thun in Wien«, vol. 4, p. 139).

13 Fragmente: "Physiognomischer Sinn, Genie, Ahndung«, vol. 4, p. 118; translation mine, E.K. Emphasis by Lavater.

14 Essays: "On the Study of Physiognomy Addressed to Count Thun, At Vienna«, p. 136 (German: »Ueber das Studium der Physiognomik, an Herrn Grafen von Thun in Wien«, vol. 4, p. 138). 
Lavater in 1786; and from the philosopher Georg Wilhelm Friedrich Hegel, who ridiculed both the physiognomic and the phrenological system in The Phenomenology of Spirit, asserting that "[s] uch an arbitrary combination of factors that are external for one another yields no law «. ${ }^{15}$ Attacks increased in number throughout the nineteenth century. Arthur Schopenhauer, although conceding that physiognomics might work in specific everyday contexts, ${ }^{16}$ denied it the status of a science. ${ }^{17}$ In England, Charles Darwin raised his critical voice against physiognomics. Off-handedly, he dismissed the question of physiognomics' scientific status on the first page of the introduction to his The Expression of the Emotions in Man and Animals:

Many works have been written on Expression, but a greater number on Physiognomy, - that is, on the recognition of character through the study of the permanent form of the features. With this latter subject I am not here concerned. The older treatises, which I have consulted, have been of little or no service to me [...]. He who thinks that remarks of this [physiognomic] kind throw any light on the meaning or origin of the different expressions, takes a very different view of the subject to what I do. ${ }^{18}$

There exists no definite terminus a quo for the decline of physiognomics and phrenology. Yet the increasing number of prominent critical voices throughout Europe, the dissolution of prominent physiognomic societies and the cessation of their corresponding journals, and the death of Europe's leading physiognomists and phrenologists all demonstrate that a decline of interest in these "scientific" systems was noticeable by the middle of the century. This development was largely completed by the turn of the century, when the Encyclopedia Britannica in 1902 expressed its surprise and displeasure about Lavater's once famous writings, "a popularity they little deserved, as

15 G.W.F. Hegel: Phenomenology of Spirit, trans. by A.V. Miller, Oxford 1977, p. 188.

16 He includes a chapter titled »On Physiognomics" in the second volume of the Parerga and Paralipomena. There, he asserts that "[t]he study of physiognomy is, therefore, one of the principal means to a knowledge of mankind." Arthur Schopenhauer: Parerga and Paralipomena: Short Philosophical Essays, 2 vols., trans. by E.F.J. Payne, Oxford 2000, here vol. 2, p. 638.

17 In The World as Will and Representation, Schopenhauer writes: "But a science of physiognomy in the abstract cannot be brought into existence to be taught and learned." Arthur Schopenhauer: The World as Will and Representation, 2 vols., trans. by. E.F.J. Payne, New York 1969, here vol. 1, p. 56.

18 Charles Darwin: The Expression of the Emotions in Man and Animals, London 1872, p. 1. 
there is really no system in his [Lavater's] work, which largely consists of rhapsodical comments upon the several portraits ${ }^{19}$

Given the fact that physiognomic and phrenological practice was slowly but surely falling into disrepute among the Victorians, it is surprising to find that it simultaneously developed into a literary device frequently employed in the realist novel. Even without solid quantitative data, the increase in physiognomic portraiture from the 1840 s is obvious to any reader of nineteenth-century fiction. Many earlier novels contained little to none physiognomic portraiture. Jane Austen's narrators, for example, never bother to describe characters' faces. While we learn already in the first sentence of the novel Emma, that Emma Woodhouse "was handsome, clever, and rich «, ${ }^{20}$ we are never informed whether she was blonde or brunette, whether she had high cheekbones, a protruding forehead, or a Greek nose. And although Sir Walter Scott is often credited with detailed physiognomic portrayal in his novels, ${ }^{21}$ a closer look reveals his disinterest in facial details and his preference for more superficial descriptive passages. ${ }^{22}$ Despite some isolated examples that make use of extensive physiognomic portraiture, ${ }^{23}$ literary physiognomics in Great Britain first came to a full start with the advent of literary realism in the 1840 s, which is some time after the heyday of sscientific physiognomics. It was used to support the realist enterprise to depict the world ras it is $<$, by describing its visible exterior. Narrators, particularly heterodiegetic ones, would use physiognomic portraiture to give their readers a concise picture of their characters' inner lives. With its excessive focus on both characters and the visible world, British realism found in literary physiognomics a device ideally fitted to its purposes, as the following considerations on physiognomics in Charlotte Brontë's realist novels shall demonstrate.

19 Art. "Physiognomy«, in: Encyclopædia Britannica, 10 ${ }^{\text {th }}$ ed., London 1902, http:// www.1902encyclopedia.com/ (last accessed 29 November 2015).

20 Jane Austen: Emma, ed. by Fiona Stafford, London 2003, p. 7; my italics, E.K.

21 Cf. Graeme Tytler: Physiognomy and Identity in Villette, in: Brontë Studies 38/1 (2013), pp. 42-53, here p. 42.

22 See Wilfred Minnich Senseman: Demi-Science and Fiction. The Utilization of the PseudoScientific in Some English Novels of the Period from 1790 to 1840, Dissertation, University of Michigan 1950, p. 250.

23 The few notable exceptions of authors with novels with detailed physiognomic descriptions that Jeanne Fahnestock lists in her wide-ranging article are largely uncanonical examples, as for instance Charlotte Mary Yonge, Jane Porter, Susan Ferrier, Julia Kavanagh, and G.A. Lawrence. See: Jeanne Fahnestock. The Heroine of Irregular Features: Physiognomy and Conventions of Heroine Description, in: Victorian Studies 24 (1980/81), pp. 325-350. 


\section{Physiognomics in Charlotte Brontë's Novels}

Chapter 13 of Charlotte Brontë's Fane Eyre describes the first days at Thornfield after Rochester's return. Many long hours provide the heroine with ample time to scrutinize her employer's face:

[T] he fire shone full on [Rochester's] face. I knew my traveller with his broad and jetty eyebrows; his square forehead, made squarer by the horizontal sweep of his black hair. I recognised his decisive nose, more remarkable for character than beauty; his full nostrils, denoting, I thought, choler; his grim mouth, chin, and jaw - yes, all three were very grim, and no mistake. His shape, now divested of cloak, I perceived harmonised in squareness with his physiognomy: I suppose it was a good figure in the athletic sense of the term - broad chested and thin flanked, though neither tall nor graceful. ${ }^{24}$

The succinct portrait is obviously more than just a meticulous description of Rochester's face (producing what Roland Barthes would call an effet de réel). It is also a physiognomic portrait that invites interpretation of the facial features mentioned. Its density is remarkable. It consists of 101 words, nine of which are the names of facial features: eyebrows, forehead, hair, nose, nostrils, mouth, chin, jaw, and the face itself. Preceding these nine terms are eight epithets: broad, jetty, square, black, decisive, full, grim, and good. These groups, substantives and adjectives, are complemented by three relative clauses specifying the description: »his square forehead, made squarer by $[\ldots]$ «, »his decisive nose, more remarkable for [...]«, and »his grim mouth, chin, and jaw - yes, all three were very grim«. The sense of strong visuality in this dense portrait is increased by the occurrence of verbs of sensory perception, like "I recognized « and »I perceived «, as well as by the opening remark stating that there is sufficient light in the room for Jane's exhaustive perception. In addition to the strictly visual part of the portrait - the descriptive part - the first person narrator, Jane Eyre, provides a series of interpretative approaches, as the verbs of cognitive processing demonstrate: "I knew«, »I thought", »I suppose«, or »denoting«. Finally, the word »physiognomy« itself appears in the text and further suggests that the description is not only neutral and descriptive, as it may appear at a first glance, but also judgmental. An attentive and physiognomically informed reader will, in all

24 Charlotte Brontë: Jane Eyre, ed. by Stevie Davies, London 2006, p. 141 (chapter 13). Chapter numbers are given after page reference for the convenience of readers with different editions. Fane Eyre is henceforth cited as JE. 
likelihood, identify the physiognomic code underlying the facial description. Its function in the narrative text is that of a double characterization; it gives information on both physiognomic reader and physiognomic object.

The sentences of this and many other similar portraits in Brontë's novels are arranged paratactically and according to the rhetorical principle of the cumulatio. The style imitates a scientific description, aiming at both completeness and exactitude. Later portraits in the novel include more or less obvious jargon from the ssciences of physiognomics and phrenology, for instance when Jane tells the "gypsy" (in truth Rochester in disguise) what she has been "detecting $[. .$.$] in his face", to which he replies, »Detecting! You$ have analysed, then " (JE, 231, chapter 19), or when Rochester points out the extraordinary development of Jane's "organ of Adhesiveness" (JE 288, chapter 23). Even where physiognomic jargon is missing, the paratactic style provides the air of exact scientific analysis, as the following description of the perfect beauty of Rosamond Oliver in Fane Eyre clearly shows:

No charm was wanting, no defect was perceptible; the young girl had regular and delicate lineaments; eyes shaped and coloured as we see them in lovely pictures, large, and dark, and full; the long and shadowy eyelash which encircles a fine eye with so soft a fascination; the pencilled brow which gives such clearness; the white smooth forehead, which adds such repose to the livelier beauties of tint and ray; the cheek oval, fresh, and smooth; the lips, fresh too, ruddy, healthy, sweetly formed; the even and gleaming teeth without flaw; the small dimpled chin; the ornament of rich, plenteous tresses. (JE 418, chapter 31)

The description consists of one single sentence divided by twelve commas and ten semicolons. It has an anaphoric structure (»the long [...] the penciled $[\ldots]$ the white $[\ldots]$ the cheek $[\ldots]$ the lips $[\ldots]$ the even $[\ldots]$ the small $[. .$.$] «),$ and a somewhat excessive number of 29 adjectives that can be grouped in adjectives of color (dark, shadowy, white, ruddy), size and mass (large, long, rich, full, plenteous), perfection (delicate, fine, regular, even, without flaw), and texture (smooth, soft), describing nine facial features (eyes, eyelashes, eyebrows, forehead, cheek, lips, teeth, chin and tresses). Again, this immoderate description suggests a scientific enumeration, which tries to completely describe an object in all its different aspects, and as precisely as possible. In the realist novel, literary physiognomics performs more than just the single function of characterizing physiognomic reader and object. It also becomes oddly relevant for the plots themselves. The afore-mentioned scene in which Rochester, disguised as a "gypsy", pretends to be reading Jane's physiognomy (after a failed attempt of chiromancy) is a curious set-up that 
marks the beginning of his courtship of Jane. Rochester first maneuvers Jane into admitting her physiognomic skills and interest, then asks her whether she likes one face in particular, hoping she might confess her affection for him. ${ }^{25}$ When he inquires what Jane finds in the faces she reads, she answers that "[t]hey generally run on the same theme - courtship; and promise to end in the same catastrophe - marriage " (JE 230, chapter 19). He then reads her face, eyes, mouth, brow, and forehead, and concludes by saying, »I have formed my plans - right plans I deem them, " when he ends the masquerade: "And Mr Rochester stepped out of his disguise" (JE 233-234, chapter 19). It is only because of the arrival of Richard Mason, the brother of his wife, Bertha Mason, whom he hides in the attic of Thornfield, that Rochester's physiognomic courtship is interrupted - just as his marriage to Jane is interrupted by Mason's second arrival in chapter 26.

Physiognomics in Charlotte Brontë's novels has a way of pairing up the right couples: initiated physiognomists like Rochester and Jane Eyre, M. Paul and Lucy Snowe in Villette, and William Crimsworth and Frances Henri in The Professor. Not only do these couples share a common interest in physiognomics, they also share similar physiognomies, a circumstance that M. Paul in Villette points out to Lucy: "[W]e are alike - there is affinity between us. Do you see it mademoiselle, when you look in the glass? Do you observe that your forehead is shaped like mine - that your eyes are cut like mine? Do you hear that you have some of my tones of voice? Do you know that you have many of my looks? ${ }^{26}$ Early critics of Brontë's novels have taken offense at such odd physiognomic similarities. A contemporary review of Fane Eyre by critic Elizabeth Rigby is much to the point: »The hero and heroine are beings both so singularly unattractive that the reader feels they can have no vocation in the novel but to be brought together. ${ }^{27}$ Disconcerting as such oddities may seem to us today, they are, strictly speaking, a logical

25 Earlier in the novel, in chapter 14, he catches her secretly analyzing his physiognomy, before he invites her to continue her examination openly: "He had been looking two minutes at the fire, and I had been looking the same length of time at him, when, turning suddenly, he caught my gaze fastened on his physiognomy. 'You examine me, Miss Eyre, said he: do you think me handsome? [...] Criticise me: does my forehead not please you? He lifted up the sable waves of hair which lay horizontally over his brow, and showed a solid enough mass of intellectual organs, but an abrupt deficiency where the suave sign of benevolence should have risen" (JE 153-154, chapter 14).

26 Charlotte Brontë: Villette, ed. by Helen M. Cooper, London 2004, p. 407 (chapter 31). Henceforth cited as V.

27 Elizabeth Rigby as quoted in: Harold Bloom (ed.): Bloom's Classic Critical Views: The Brontës, New York 2008, p. 75. 
consequence of Lavater's theory. If Jane and Rochester are alike in character, and if inner character can truly be read on the outer surface, then they must also have a similar appearance. ${ }^{28}$

\section{Pseudo-Scientific Racism}

Physiognomic pairing in Brontë's novels facilitates the protagonists' search for an appropriate partner. Yet, at the same time, it effectively forecloses any possibility for non-physiognomists to marry an initiate of the sscience.< The physiognomic readings of Jane Eyre, Lucy Snowe, M. Paul, and William Crimsworth are always correct, detailed, and fast, but they are hardly "designed to promote the knowledge and the love of mankind, " which after all is the central concern of physiognomics according to the subtitle of Lavater's Essays. They rather widen the gap between Britons and continental Europeans or non-Europeans, where the latter group commonly appears inferior to Brontë's British physiognomists. The features of Bertha Mason, Rochester's first wife, who he keeps locked up in the attic of Thornfield, appear to Jane as

[f]earful and ghastly [...] - oh, sir, I never saw a face like it! It was a discoloured face - it was a savage face. I wish I could forget the roll of the red eyes and the fearful blackened inflation of the lineaments! [...] [T] he lips were swelled and dark; the brow furrowed: the black eyebrows widely raised over the bloodshot eyes. Shall I tell you of what it reminded me? [...] Of the foul German spectre - the vampire. (JE 327, chapter 25)

Rochester later confirms what Jane's description of the Jamaican wife's physiognomy had already and unmistakably told: that Bertha Mason's "cast of mind [was] common, low, narrow, and singularly incapable of being led to anything higher, expanded to anything larger [...]. What a pigmy intellect she had, and what giant propensities! (JE 353, chapter 27) Unsurprisingly, Rochester soon desires to break off the relationship to his wife, who »the doctors now discovered [...] was mad" (JE 353, chapter 27), and he decides to lock her away in his attic. He insinuates that his mistake may have been

28 While the similarity might well be as astonishing as it is in the case of Lucy and M. Paul, according to Lavater it can never stretch to identical looks, as it is a key point in Lavater's argument that not two physiognomies in the world are fully identical: "Nor is it less incontrovertible that it is equally impossible to find two minds, as two countenances, which perfectly resemble each other.« Essays: "Of the Truth of Physiognomy«, p. 13 (German: "Von der Wahrheit der Physiognomie«, vol. 1, p. 45). 
avoided, had he been a better judge of human character in his youth, but, he admits, that on first sight of Bertha Mason he "was dazzled, stimulated: my senses were excited; and being ignorant, raw, and inexperienced, I thought I loved her" (JE 352, chapter 27). The older Rochester's physiognomic skills safeguard against similar mistakes, and he chooses Jane as his second wife, "to be my second self" (JE 293, chapter 23), as he puts it. And she is indeed much like him: both in physiognomic appearance and physiognomic skill. "[I]t is, « he tells her, "as if I had a string somewhere under my left ribs, tightly and inextricably knotted to a similar string situated in the corresponding quarter of your little frame." (JE 291, chapter 23) The knot that ties Jane and Rochester together (as it does with the characters in Brontë's other novels) simultaneously separates them from all the other, non-British characters: After all, Jane identifies "the vampire" as a "foul German spectre," while Rochester complains about Bertha's "pigmy intellect « [my italics, E.K.]. As Jane's narrative clearly demonstrates, she and Rochester truly belong to each other, as Britons prejudiced against all non-Britons. Their double physiognomic resemblance produces analogies and differences at the same time. The scientifically objective style of the physiognomic descriptions in the novel seems to put such prejudices on solid ground, thus indirectly asserting the rights of British hegemony. ${ }^{29}$

In the realist novels of the 1840s and 1850s, of which Brontë's is but one example, Lavater's philanthropic concept - if we want to buy into it at all - is translated into a racist ideology that anticipates to some extent the appropriation of physiognomic and phrenological theory through criminal anthropology (Cesare Lombroso), eugenics (Francis Galton), and raciology (Ernst Rüdin). ${ }^{30}$ Similar to these pseudo-sciences, literary physiognomics uses an allegedly exact science to prove the superiority of the assiduous, devout, loyal British man. In the face of these racist tendencies, the judgments within the fictional world of fane Eyre and and other novels must appear as prejudices. In other words, they commit what philosophers since

29 This trend does not solely pertain to Great Britain. Heinrich Heine, for instance, satirized the hegemonic ambitions of Germany in his satirical epic poem, Germany. A Winter's Tale (Deutschland. Ein Wintermärchen [1844]): "Franzosen und Russen gehört das Land, / Das Meer gehört den Briten, / Wir aber besitzen im Luftreich des Traums / Die Herrschaft unbestritten. / Hier üben wir die Hegemonie, / Hier sind wir unzerstückelt; / Die andern Völker haben sich / Auf platter Erde entwickelt. "Heinrich Heine: Deutschland. Ein Wintermärchen, Frankfurt a.M. 2010, p. 29 (Caput VII).

30 Cf. Cesare Lombroso, L'uomo bianco e l'uomo di colore (1871); Francis Galton, Hereditary Genius (1869); Ernst Rüdin (ed.): Erblehre und Rassenhygiene im völkischen Staat (1934). 
Gilbert Ryle have called a scategory mistake ${ }^{31}$ Instead of reading the inner character on the face, they read the inner character into the face. Whether unintentionally, because they are convinced of the validity of their own physiognomic judgments, or intentionally, because they have realized that physiognomics, if rightly applied, can become a valuable means of selfassertion, the texts do not say.

What these texts do reveal, however, are narratives of isolation. Although the autodiegetic narrators in Brontë's novels are English, they suffer social ostracism and are excluded from their class (The Professor), from their families (Fane Eyre), or from society at large (Villette). ${ }^{32}$ All three leave their place of origin to start over at some other place, often on the continent (The Professor, Villette). The other place is always inhabited by people of different nation, religion, or class. There, the protagonists attempt to forge themselves new identities, equipped with nothing but their natural abilities. The former ostracism of the narrator (genitivus obiectivus) turns into the dissociation of the narrator (genitivus subiectivus).

In the 1840s and 1850s, both physiognomics and phrenology coalesced with the nascent ideology of self-help that was later popularized by Samuel Smiles's book of the same title. It was closely related to the realist project, to describe "real living men, " as Brontë writes in the preface to The Professor, working their "way through life.$^{33}$ Brontë's realist protagonist "should never get a shilling he had not earned [...]; that whatever small competency he might gain should be won by the sweat of his brow [...]. As Adam's Son he should share Adam's doom - Labour throughout life and a mixed and moderate cup of enjoyment " (TP 3). Work and gain, labor and earn: This is the economy of nineteenth-century self-help ideology. However, self-help is a double-edged sword. On the one hand, it potentially allows for social mobility, while on the other hand it constitutes, as Heather Glen argues, a "Society< composed of competing, self-interested individuals $« .{ }^{34}$ It affirms

31 According to Gilbert Ryle, we deal with a category mistake when "people who are perfectly competent to apply concepts, [...] are still liable in their abstract thinking to allocate those concepts to logical types to which they do not belong." Gilbert Ryle: The Concept of Mind, ed. by Julia Tanney, London/New York 2009, p. 7.

32 Of Brontë's four finished novels, Shirley, with its heterodiegetic narrator and its historical setting of the Continental Blockade and, later, the French invasion of Russia, forms an exception. Nevertheless, traces of physiognomically expressed xenophobia, particularly Francophobia, can be found in Shirley as well.

33 Charlotte Brontë: The Professor, ed. by Margaret Smith and Herbert Rosengarten, Oxford 2008, p. 3. Henceforth cited as TP.

34 Heather Glen: Charlotte Brontë: The Imagination in History, Oxford 2006, p. 47. 
values that Brontë associates with an Anglican upbringing: frugality, diligence, conscientiousness, and self-reliance. Simultaneously, it tends to denigrate any opposing value, i.e. anything that is non-British, although these systems appear most alluring to Brontë's protagonists, who constantly feel the need to restrain themselves. In Villette, for instance, Lucy Snowe feels a strong urge to entrust herself to the Catholic priest Père Silas:

That priest had arms which could influence me; he was naturally kind, with a sentimental French kindness, to whose softness I knew myself not wholly impervious. Without respecting some sorts of affection, there was hardly any sort, having a fibre of root in reality, which I could rely on my force wholly to withstand. Had I gone to him, he would have shown me all that was tender, and comforting, and gentle, in the honest popish superstition. Then he would have tried to kindle, blow and stir up in me the zeal of good works. I know not how it would all have ended. (V 180, chapter 50) ${ }^{35}$

In the end, however, she always finds the strength to resist »Popish superstition" and similar temptations. To know bad influence at a glance requires knowledge of human nature, which, according to Lavaterean tenets, can be gained through physiognomic analysis. Since, as I have already suggested, physiognomic judgements in Brontë's fiction almost always come in the shape of prejudices, physiognomics only affirms (and thereby excludes) what Smilesian self-help ideology had deemed as suspicious in the first place: idle foreigners. Conveniently, such characters can easily be kept at bay since they do not have the same physiognomic abilities at their command as the protagonists. Brontë's Britons are, therefore, almost always at a (physiognomic) advantage.

35 Similar temptations can be found in all the other novels by Charlotte Brontë, too. In fane Eyre, the character of St. John personifies resistance to any possible temptation: »The humanities and amenities of life had no attraction for him - its peaceful enjoyments no charm. Literally, he lived only to aspire - after what was good and great, certainly; but still he would never rest, nor approve of others resting round him. [...] I understood, as by inspiration, the nature of his love for Miss Oliver; I agreed with him that it was but a love of the senses. I comprehended how he should despise himself for the feverish influence it exercised over him [...] (JE 453, chapter 34). Crimsworth in The Professor first falls in love with Zoraïde Reuter, but when he overhears a conversation between her and M. Pelet, in which they make fun of him, he needs to reinterpret his disappointment as achievement: "Reason was my physician; she began by proving that the prize I had missed was of little value: she admitted that, physically, Zoraide might have suited me, but affirmed that our souls were not in harmony, and that discord must have resulted from the union of her mind with mine. She then insisted on the suppression of all repining, and commanded me rather to rejoice that I had escaped a snare. Her medicament did me good« (TP 95, chapter 13). 


\section{Conclusion}

As my investigation of passages from Charlotte Brontë's three realist novels, The Professor, Fane Eyre, and Villette, has shown, British literary and scientific physiognomics began to diverge by the mid-nineteenth century. The growing number of critical voices brought physiognomic practice into disrepute. Yet, at nearly the same time, writers began to systematically employ literary physiognomics in their novels as a means of both an allegedly objective and scientific characterization, and as a plot device. While real-life physiognomics never achieved the status of an exact science that could infallibly access man's inner character, literary physiognomics in the realist novel Charlotte Brontë being a case in point - soon became fully operational in this regard. The able physiognomists in Brontë's fiction, originally social outcasts, use their physiognomic skills to advance their position in life by distinguishing between good and bad company. On the face of it, this connection between an allegedly objective literary physiognomics and the nascent British self-help ideology enables Brontë's protagonists to make their way in life and to find a community in which they are accepted. The price for the social rehabilitation of these outsider characters is the exclusion of others: a reproduction of the ostracism they once suffered themselves. Where literary physiognomics gains scientific solidity, it loses its original, Lavaterean philanthropic assertion and develops into a tool of power for self-interested individuals. The problem of physiognomics in Victorian realism was not that a pseudo-science achieved the ranks of a solid science, but rather that an allegedly scientific practice was misused to 'prover common resentments and to unilaterally regulate the distribution of hegemonic demands. Only with the advent of literary modernism in the late novels of George Eliot, in the works of Thomas Hardy, or Joseph Conrad, did literary physiognomics realize the fallacy of its former deployment. Consequently, it slowly but surely lost ground, until its full disappearance in the high modernist writings of Woolf, Ford, Joyce, and others. 
